\title{
CONSUMER PROTECTION IN FINANCIAL SERVICES. PRICES AREA
}

\author{
Piotr Masiukiewicz \\ Warsaw School of Economic \\ Institute of Value Management \\ 162 Niepodległości al.,Warsaw, Poland, 02-554 \\ piotr.masiukiewicz@wp.pl
}

\begin{abstract}
The important area of customers' protection it is decided of prices. Law strict injunctions of application of some specific types of prices existence in all development countries. Bans on certain categories of prices are present in legal systems of all developed countries; UE directives and OECD guidelines contain bans on price discrimination through dumping, price fixing cartels or transfer price fixing. In this paper are showed the institutional models of customer's protection in area of prices in credit institutions (for example interest rate). In the area of financial services the prices have specific character, for example reference prices, preferential prices, compound prices, risk of a price change, different prices for the same product, payment by instalments. Contrary to the rules are showed in case study of banking market in Poland. Law regulations of interest rate are much wider applied than prices regulations on the other markets.

The development of protection institutions of customers in the banking market influenced more compliance law and ethical rules in price proceeding. Bad more education of customers it's necessary. One of the misgivings signaled by banks is growing restrictiveness of regulations on consumer protection, which should become a subject of in-depth research.
\end{abstract}

Keywords: customers, financial supervision, interest rate, law, loan, market, price in bank, prohibit prices, regulations, protection.

\section{Introduction}

European Union law contains numerous consumer protection regulations. Incorporation of consumer protection principle into the Treaty on European Union signed at Maastricht (art. 103.3 and 129a) has been a significant stage in pro-consumer policy development. Many EU directives and recommendations relate to this issue. These are among others: the directive on unfair terms in consumer contracts, recommendation relating to electronic payment, the directive on consumer credit, the directive on cross-border supply of financial services and the directive on misleading advertising.

Price setting constitutes a significant segment of consumer protection issues. Bans on certain categories of prices are present in legal systems of all developed countries; UE directives and OECD guidelines contain bans on price discrimination through dumping, price fixing cartels, or transfer price fixing. Since not all legal regulations are precise, national court judgmentsand CJEU judgments play a significant role. Managers of financial institutions responsible for pricing policies are not always aware of civil or even criminal liability for erroneous decisions in this area.

The aim of this paper is to review institutional solutions regarding customers' interests' protection in the area of credit institutions' prices. Existing shortcomings in this area are presented with Poland as an example.Analyses and research point to actual problems with ethical pricing and price intelligence [1].

The notion of price in financial services sector means interest rates, discount, commissions and fees as well as security prices and exchange rates.

\section{Specific nature of financial services pricing and forbidden price construction}

In general prices are results of economic decisions of both a seller and a buyer of a product [2-5] The client perceives the price, assimilates it and makes a decision according to following formula:

[Price for the customer $=$ individual benefit evaluation + + fulfillment of the need (price acceptance) + satisfaction with the purchase]. 
According to J. Stiglitz, financial instruments are sales subjects of a bank. They are specific monetary promises. This seems to be an apt and concise definition; although it is lacking the temporal factor. In financial institutions money is a commodity, always sold for a certain period of time. It's actually time that determines its price.

Specific character of the price of financial services depends on:

- reference prices (e. g. of central bank);

- different prices for the same product;

- compoundprices;

- payment by instalments;

- risk of a price change (interest rate, currency risk, derivatives price);

- change of the price after the transaction (variable interest rates);

- risk costs lead to higher prices;

- pricesubsidies (preferentialrate);

- credit payment guarantee by the client (bank guarantees, sureties, material collateral) as well as deposit payments by a guarantee fund;

- mutual financing of products by the prices (cross subsidization).

From the consumer protection's point of view one can identify excessive prices (unaffordable for an average client), prices prohibited by the law and misleading prices on the market $[6,7]$.

The specific character of price strategies of banks can be also linked to special effects (dysfunctional effects) of pricing strategiespracticed on the financial market. [7, 8]. Table 1 illustrates main pricing special effectson the financial market, described in literature.

Table 1

Special effects of prices in financial market

\begin{tabular}{cccc}
\hline No & General disfunktionaleffects & No & Special effectsin financial services \\
\hline 1 & Compound priceseffect & 1 & Compensationeffect \\
2 & Medial effect of price & 2 & Nonmarket price effect in financial enclaves \\
3 & Cannibal effect & 3 & Crowding effect \\
4 & Substitutioneffect inter marketing instruments & 4 & New priceeffectby Veblen \\
5 & Carrier forward effect(transferable acquire of price) & 5 & Interest-free products(in Islamic banking) \\
6 & Flexibility price of advertising & &
\end{tabular}

Source: finalized in accordance [6]

Legal bans on certain types of prices are present in all developed countries; bans on dumped, cartel fixed or transfer prices appear in EU directives (Fig. 1). Misleading prices mean false presentation of the real value of the sold products. Like for instance prices given without VAT added, media prices (present in the ads, practically unavailable for the clients), or compound prices given without their certain components (e. g. without a commission which is treated not as an element of the price, but as an element of interest). Price discrimination means giving different prices of the same product sold under comparable sales terms for different consumer groups. In many countries such practices are illegal. For instance in the USA the Robinson-Patman Act prohibits different pricing for the buyers of the same product.

Most common price distortions are [5, 6, 9]:

- interest-freerate (only commissions and fees for loans);

- discount rate as a basis for an algorithm to calculate simple or compound interest;

- base rate algorithms constricting current reactions to market changes;

- depositcommissions, complaint fees, excessive accrued interest etc.;

- ignoring price caps established by financial supervisors (banks in crisis implementing repair programs);

- misleading price ads, media prices;

- anti-tax deposits; including policy-investments (the price is lower than it would be with the income tax); 
- misleading prices: e. g. showing the interest cost for the clients instead of presenting the real rate or offering a discount credit (i. e. interest paid in advance);

- unavailability or unreliability of price information in the offers.

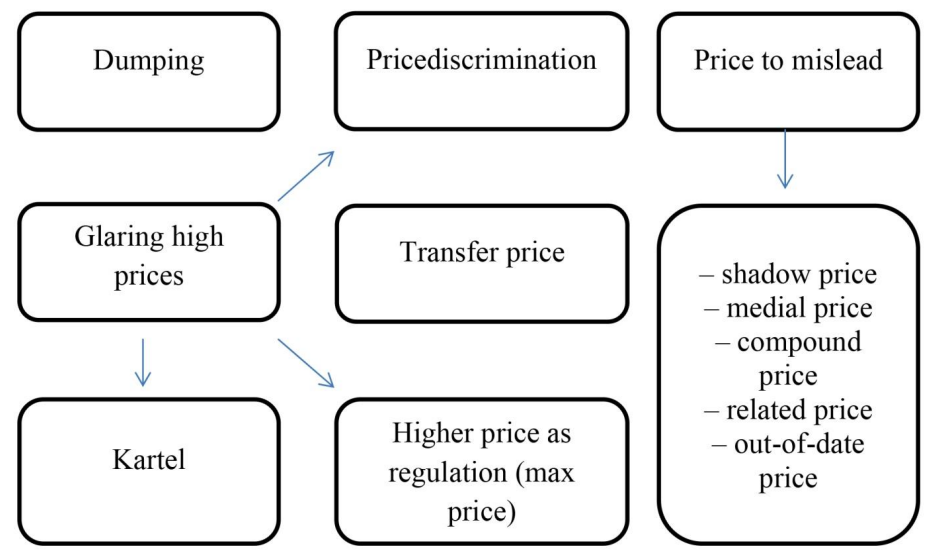

Fig. 1. Prohibit and mislead types of prices

Source: own

Banks' offers sometimes include so called media prices - which arevery favorable, but the financial product is accompanied by so many conditions, it's available only for one client in a million.

Institutional system of consumer protection should prevent the above bad practices; unfortunately it not always manages to do so.

A major problem nowadays is that some enterpriseslose their capability of conscious pricing, or so called price intelligence. Price intelligence is based on clients' price perception, competitors' price strategy evaluation, commoditization level evaluation and it is also one of the key factors that determine viability of an enterprise [1].

\section{Institutional protection models}

As far back as the XIX century costs of basic commodity that money is in banks were controlled, while banks' competitive activities were determined to a certain degree by legal regulations $[2,3,10]$. Financial regulations covered both functioning of financial markets and financial institutions (especially banks) and they were concerning mostly deposit and credit interest rates, fees and commissions, credit quotas and sector structure. Such strong regulations were aimed at securing stability within the banking sector and protecting itfromunfair competition. In the 90s prudential regulations were widely developed to prevent excessive risk [2, 4].

There are two models of financial sector consumer protection in economic practice, e. g.: national consumer protection board widely cooperating with social organizations that also deals with financial market problems and a model based on expert consumer protection boards (including financial supervisory authorities) or on an office of ombudsman for financial market (Fig. 2). There is also a mixed model (for instance in Poland).

A new consumer protection institution, created in many countries is a financial spokesperson (financial ombudsman). The first country that established such office was the USA. In Poland the first financial ombudsman has been appointed in the year 2015.

What's really important, is periodical evaluation of institutional systems' efficiency. According to the Supreme Audit Office (NIK) report - protection of the financial market clients in the years 2011-2013 wasn't efficient. Although The Office of Competition and Consumer Protection (UOKiK), Financial Supervision Authority (KNF), Insurance Ombudsman and local consumer ombudsmen wereacting in accordance with the law, they could not ensure efficient protection for the financial market clients. That's why the percentage of faulty agreement forms was high and the amount of complaints regarding the financial market institutions was growing. Unclear competence division between institutions responsible for consumer protection discouraged aggrieved 
clients to claim their rights. Another problem was a practically not functioning arbitration while procedures in common courts were lengthy. According to European Commission researchб the level of consumer trust for public consumer protection institutions in Poland was amongst the lowest in EU [11].

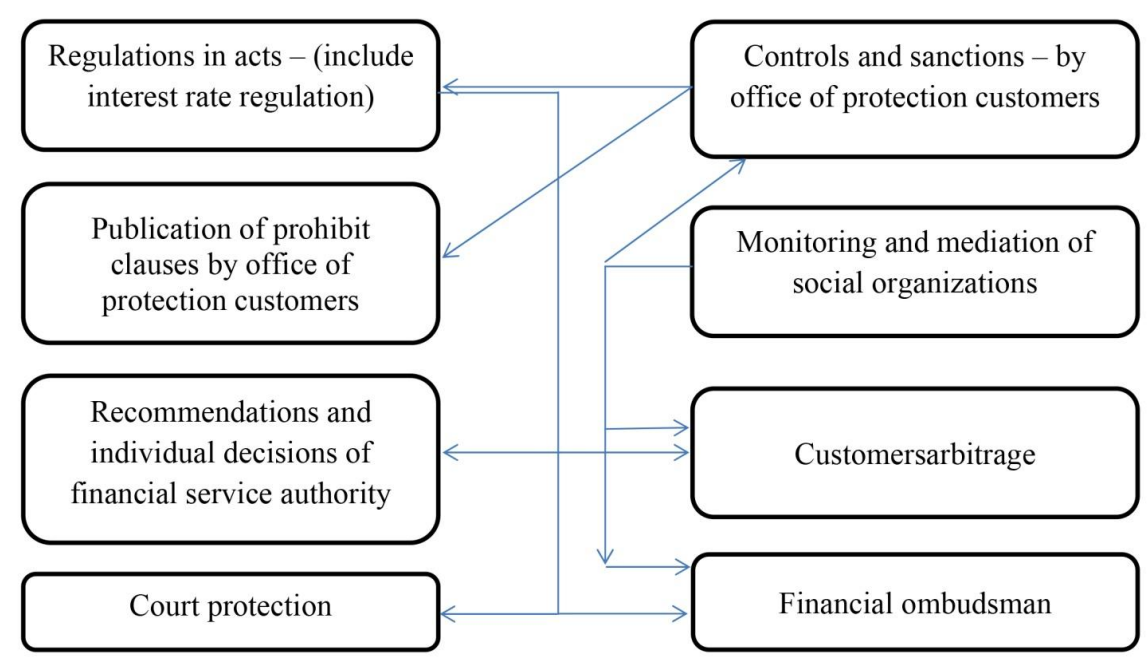

Fig. 2. Institutional protection of customers in financial services Source: ownstudy

\section{Price regulations in banks. Example of Poland}

Consumer protection effectiveness grows with the awareness and knowledge on the protection itself. Unique research of Polish banks' clients show, that only $14 \%$ of them evaluate their knowledge as good or very good (Table 2) [12].

Table 2

Customers knowledge about rights which vested in contact with bank $(\mathrm{N}=1000)$, answers in \%

\begin{tabular}{|c|c|c|c|c|c|c|}
\hline No & Contents & Verygood & Good & Middle & Low & Not \\
\hline 1 & Total customers-respondents & 2,0 & 12,0 & 37,4 & 39,9 & 8,6 \\
\hline 1.1 & Include:customers with university education $(\mathrm{N}=143)$ & 3,3 & 20,0 & 40,0 & 34,1 & 2,5 \\
\hline
\end{tabular}

Source: Dąbrowska A. Janoś-Kresto M., Ochrona konsumentów na rynku ustug bankowych i telekomunikacyjnych, Oficyna Wydawnicza SGH, Warszawa, 2012, p. 31 [13]

Pricing strategies in Polish banks have many limitations contained in the law. This applies to interest rates, commissions and fees. The most significant regulation is the maximum price limit for consumer credits implemented in 2005 [7]. There's also a ban on crediting in Argentinian system in Poland.

Price regulations in banks are very wide (Table 3). One could even define the situation as market overregulation [4, 14].

An important regulation in prices area is implementation of maximum prices of consumer credits as a result of a change of civil code in 2005 (so called anti-usury act) [15]. It is an example of a state regulated price and a debatable one in the light of a principle of free price formation by economic entities. A regulation was implemented that maximum annual interest rates resulting from a legal transaction can't exceed quadruple of Lombard credit rate of National Bank of Poland (NBP). The above act also introduced changes into the act on consumer credit, establishing maximum fees, commissions and other costs of consumer credit. The maximum sum of all the fees can't exceed $5 \%$ of the credit. An obligation to calculate and present to the client the annual percentage rate was also established $[13,14]$. It is a rate that takes into account the interest rates, commissions and fees. Breaching those resolutions is a criminal offence punishable by deprivation of liberty. 
Table 3

Price regulations on credit institutions market in Poland in 2015

\begin{tabular}{|c|c|c|c|}
\hline Regulatory area & Types of legalacts & Number of legalacts & Comments \\
\hline $\begin{array}{l}\text { 1. Interest rates on credits and } \\
\text { preferentialpricesof credits }\end{array}$ & Acts and regulations & 15 & $\begin{array}{l}\text { Preferential prices of } \\
\text { credits - state subsidies }\end{array}$ \\
\hline 2. Reference rates & Acts, MPCresolutions & 5 & \\
\hline 3. Statutory interest & Acts and regulations & 4 & \\
\hline 4. Consumer protection & Acts and regulations & 8 & \\
\hline 5. Otherareas of regulation & Acts, regulations and resolutions & 14 & $\begin{array}{c}\text { (acts: on prices, on competition, bank } \\
\text { law, advertisement law) }\end{array}$ \\
\hline Together & $\mathrm{X}$ & 46 & $\mathrm{X}$ \\
\hline
\end{tabular}

Source: ownstudy

During the works on the act many critical publications appeared [7, 14]. Critics of this solution pointing out to high risk clients being deprived of a chance of taking a bank credit. They also warned that banks will demand high and costly guarantees, there might be a threat of common practice of maximum interest rateapplied regardless of risk, works on product innovation will stop, the offer of currency credit will get bigger, a grey credit market will develop, etc. It's been also pointed out that maximum limits exist only on German and French markets where the offer for high risk clients is poorer and willingness to use illegal consumption financing sources is 2,5-3 times higher.

In special cases (like bank crisis) Polish Financial Supervision Authority can obligate a bank to use maximum limits of deposit interests, defined by theAuthority. It is a disputable solution.

New problems appeared also in bank pricing strategy implementation. They are related among others to functioning in an environment of very low interest ratesduring recent years. From 2015 there's been anongoing debate in Poland on bank or state help (subsidy) for the clients, who had taken mortgage loans in Swiss francs in the 90's [16]. According to election promises a draft law was prepared on helping those who took credits in Swiss francs but it was called in question by Polish Financial Supervision Authority.It's legally doubtful whether one can force banks to pay same compensation to those clients just because of a (unfortunately high) rise of Swiss franc's exchange rate. The more that all the contracts with clients contained information about the currency risk, and before the rise those credit takers did take advantage of low prices and interest rates.

Unfair and unethical price information appears in banks' offers. For instance National Bank of Poland (NBP) (its strategic owner is The State Treasury) offered in 2016 a consumer credit with $1 \%$ interest, which was heavily advertised (TV, press, leaflets). However there was informationin the ads in small print that $1 \%$ interest rate goes only for half a year while the commission goes up to $9.99 \%$. Total cost of this credit expressed in annual percentage rate goes up to $45.75 \%$, while deposits are accepted with interest rates of $1-2 \%$ per cent! That's an example showing that some bank managers still have problems with business ethics [17].

On the basis of a survey P. Chwirot-Zakrzewska concluded [3] that all surveyed universal banks on Polish market apply price discrimination (none of the surveyed banks applied identical prices of the same services). The research shows that price discrimination practiced by those banks was based on different bases. Furthermore, it was noted that sometimes one bank uses different criteria of price discrimination in relation to the same or different services or groups of clients. Among the key criteria of price discrimination used by surveyed universal banks three types of discrimination were identified: discrimination based on the client, discrimination based on distribution channels and geographical discrimination. The research did not confirm discrimination based on the seasons of the year or different times of the day in universal banks [3]. 
The results of Supreme Audit Office inspections are disturbing. According to its report functionality of the register of forbidden contractual clauses, kept by the Office of Competition and Consumer Protection was limited. A serious extension of the registry (at the end of the first half of 2013 it contained nearly 5300 entries) made it more difficult to use. By the end of the period of scrutiny significant improvements in this area haven't been implemented. Over 60 per cent of agreement templates used by controlled entities on the financial market in commercial relationships with consumers included provisions incompatible with the legal rules or breaching consumers' interests. That points out to high risk for financial market clients in Poland [11].

Making decisions on credit and loan prices without taking into account existing law would create a risk of criminal sanctions for policy makers. According to Polish law - whoever, in connection with the performance of a managerial post in an organizational unit that carries out economic activities, or having - because of his/her position - significant impact on making decisions on functioning of the unit, accepts material (or personal) benefits or promise thereof in exchange for behavior that could be harmful to the unit's financial wellbeing or for an unfair competition deed or inadmissible preferential activity for the purchaser or the recipient of the goods, services or benefits, shall be subject to the penalty of the deprivation of liberty for a term of between 3 months and 5 years. Undoubtedly that covers such activities like concealment of actual creditworthiness of a client, unjustified exemption from charges, lowering the interest rates as well as applying dumped prices. If the perpetrator of these deeds has caused significant material injury to his/her company shall be subject to the penalty of deprivation of liberty for up to 8 years. In case of conviction for the offence by which the perpetrator obtained significant benefits, property he took into possession or gained the title to during committing the offence, constitutes benefit from the criminal offence. (Act dated 13.06.03r. on amending the law - Criminal Code and some other laws).

\section{Conclusion}

Price regulating on the bank market, especially in relation to banned prices are currently important for consumer protection. Excessive restraining of financial market with legal regulations may have negative impact on price competition and turn against customers. Therefore government policy and pricing strategies of banks should be well balanced. A question still remains, whether there are too many regulations already present under market economy conditions; especially the regulations on credit prices. All these questions should be widely taken into consideration in codes of business ethics of different financial sectors.

According to marketing approach the price is effective only if it's market-oriented because only then pricing is a creative process, generating competitive advantage rather than a simple mathematical formula, as in the case of cost-based approach.

Development of consumer protection organizations and institutions on the bank market in Poland seems to bring about better compliance with legal and ethical rules in pricing. Clients' education and economic awareness in this area also grows, although it is still insufficient. At the same time one of the concerns signaled by banks after integration of Polish credit market with European markets, is growing restrictiveness of regulations on consumer protection, which should become a subject of in-depth research.

\section{References}

[1] Zinoecker, R., Nowak, T., Świętek, G. (2012). Budowanie inteligencji cenowej. Harvard Business ReviewPl.

[2] Christl J., ed. M. Balling, F. Lierman, A. Mullineux (2006). Macroeconomic Consequences of Financial Regulation, in:Competition and Profitability in European Financial Services. Strategic, Systematic and Policy Issues. Routledge: London - New York, 2006

[3] Chwirot-Zakrzewska, P. (2010). Praktyczne zastosowanie metod kształtowania cen w bankach komercyjnych działających w Polsce. Finansowy Kwartalnik Internetowy,nr 1/2010. http://www.e-finanse.com/ artykuly_eng/136.pdf 
[4] Masiukiewicz, P. (2000). Ograniczenia konkurencji cenowej na rynku usług bankowych. Prakseologia, 140.

[5] Rao, A. R. Bergen, M. R., Davis S. (2003). Jak prowadzić wojnę cenową. Harvard Business Review Polska, 5.

[6] Masiukiewicz, P. (2007). Ceny prawnie zakazane. Prawo Europejskie, 12.

[7] Masiukiewicz, P. (2007). Marketing w enklawach finansowych. Warszawa: Difin, 190.

[8] Gourville. J., Soman. D. (2002). Pricing and the Psychology of Consumption. Harvard Business Review, 9.

[9] Płókarz, R. Specyfika polityki marketingowej w bankowości prywatnej, AnnalesUniversitatisMariae Curie-Skłodowska, section H, 43 (3), 487-496.

[10] Włodarczyk, B., Puczkowski, B. (2010). Klient instytucji finansowych wg. regulacji MIFID. Prace i Materiały Wydziału Zarządzania UG, 4 (2).

[11] Funkcjonowanie systemu ochrony praw klientów podmiotów rynku finansowego. (2014). Warszawa Raport NIK.

[12] Dąbrowska, A., Janoś-Kresło, M. (2012). Ochrona konsumentów na rynku usług bankowych i telekomunikacyjnych. Warszawa: Oficyna Wydawnicza SGH, 142.

[13] Wiśniewska, U. Eds. Szelągowska, A. (2010). Współczesna bankowość detaliczna: Ustawa antylichwiarska a ochrona interesów kredytobiorców., Warszawa: CeDeWu, 310.

[14] Gostomski, E., Lepczyński, B., Penczar, M. (2005). Wątpliwe korzyści. Bank nr 07.08.2005

[15] Ustawa z dn. 07.07.05 r. o zmianie ustawy - Kodeks cywilny oraz o zmianie niektórych innych ustaw (Dz. U. no 157/05, poz. 1316)

[16] Buszko, M. Ograniczenie wydatków z tytułu spłaty walutowych kredytów mieszkaniowych, Annales Universitatis Mariae Curie-Skłodowska, H, 3/2013

[17] PKO BP. Bank, który miał pilnować cen na rynku, podnosi opłaty. http://www.pomorska.pl/ strefa-biznesu/firma/aktualnosci/a/pko-bp-bank-ktory-mial-pilnowac-cen-na-rynku-podnosi-oplaty,10141524/ 